\title{
DAMPAK PROGRAM BANTUAN SARANA PRODUKSI PERTANIAN TERHADAP PENDAPATAN PETANI CABAI DI DESA KAUNERAN KECAMATAN SONDER
}

\author{
Ariyano Alfa Randi Siwu \\ Juliana Ruth Mandei \\ Eyverson Ruauw
}

\begin{abstract}
This study aims to determine how the impact of the Agricultural Production Facility Assistance Program on Chili Farmers' Income in Kauneran Village, Sonder District. Data collection is conducted from March to May 2018. The selection of farmer groups is done purposefully, namely the recipient farmer groups. This study uses primary data and secondary data. Primary data is obtained from direct interviews with respondents based on a list of questions (questionnaires) that have been prepared in advance and observations. Interviews were conducted on 20 respondents, namely all Kalelon group members as a recipient group of aid programs. Secondary data obtained through the internet by using google searching to access scientific journal articles and thesis from other universities has to do with the topic of this research which is about the impact of aid programs. The results showed that there were significant income differences, based on the t-test, between before and after receiving the aid program where the income of farmers after receiving assistance was greater than before receiving their assistance. The conclusion of this study is that the aid program has a positive impact because it increases farmers' income. "ertepm*
\end{abstract}

Keywords: program impact, production facilities assistance, chili farmers, t-test, Minahasa Regency

\begin{abstract}
ABSTRAK
Penelitian ini bertujuan untuk mengetahui bagaimana dampak yang ditimbulkan dari Program Bantuan Sarana Produksi Pertanian terhadap Pendapatan Petani Cabai di Desa Kauneran, Kecamatan Sonder. Pengumpulan data dilakukan mulai dari bulan Maret sampai bulan Mei 2018. Pemilihan kelompok tani dilakukan secara sengaja yaitu kelompok tani penerima bantuan. Penelitian ini menggunakan data primer dan data sekunder. Data primer diperoleh dari wawancara langsung dengan responden berdasarkan daftar pertanyaan (kuesioner) yang telah disusun sebelumya serta pengamatan. Wawancara dilakukan pada 20 responden yaitu pada seluruh anggota kelompok Kalelon sebagai kelompok penerima program bantuan. Data sekunder diperoleh melalui internet dengan menggunakan google searching untuk mengakses artikel jurnal ilmiah dan skripsi dari perguruan tinggi lainnya ada kaitannya dengan topik penelitian ini yaitu tentang dampak program bantuan. Hasil penelitian menunjukkan bahwa terdapat perbedaan pendapatan yang signifikan, berdasarkan uji-t, antara sebelum dan sesudah menerima program bantuan dimana pendapatan petani sesudah menerima bantuan lebih besar daripada sebelum menerima bantuannya. Kesimpulan dari penelitian ini adalah program bantuan memberikan dampak positif karena meningkatkan pendapatan petani. ${ }^{\text {ereteprm* }}$
\end{abstract}

Keywords: dampak program, bantuan sarana produksi, petani cabai, uji-t, Kabupaten Minahasa

\section{PENDAHULUAN}

\section{Latar Belakang}

Pertanian di Indoneisia merupakan sektor yang paling penting, dimana sebagian besar penduduknya bekerja di sektor pertanian. Banyaknya jumlah penduduk Indonesia yang menggantungkan hidupnya dari sektor pertanian menunjukkan demikian besar peranan sektor pertanian dalam menopang perekonomian dan memiliki implikasi penting dalam pembangunan ekonomi ke depan. Pembangunan di sektor pertanian tidak terlepas dari pengembangan kawasan pedesaan yang menempatkan pertanian sebagai penggerak utama perekonomian. Lahan, tenaga kerja, dan basis ekonomi lokal pedesaan menjadi faktor utama dalam pengembangan pertanian. 
Kebijakan pemerintah dalam
pengembangan pertanian bertujuan untuk
meningkatkan pendapatan dan kesejahteraan
petani sehingga dapat mengurangi kemiskinan di
sektor pertanian. Untuk mengatasi permasalahan
yang timbul di sektor pertanian, pemerintah lewat
kementrian pertanian telah meluncurkan berbagai
program bantuan. Salah satu program yang telah
di luncurkan oleh pemerintah di bidang hortikultura kepada petani adalah program bantuan sarana produksi pertanian.

Sarana produksi pertanian adalah segala jenis peralatan, perlengkapan dan fasilitas pertanian yang berfungsi sebagai alat utama atau pembantu dalam pelaksanaan produksi pertanian. Sarana produksi berperan penting di dalam usaha mencapai produksi sesuai dengan tujuan yang diinginkan. Sarana produksi pertanian atau saprotan terdiri atas bahan yang meliputi benih, pupuk, pestisida dan zat pengatur tumbuh. Sarana -sarana tersebut sudah harus tersedia sebelum memulai kegiatan budidaya tanaman.

Kelompok tani kalelon adalah kelompok tani terbaik yang telah menjadi contoh dan teladan di Kecamatan Sonder terlebih khusus di desa Kauneran dimana kelompok tani kalelon ini telah banyak mendapatkan bantuan dari pemerintah. Adapun jenis usaha pertanian yang di usahakan kelompok tani kalelon adalah jagung, bawang merah dan cabai. Pada awal tahun 2017 kelompok tani kalelon kembali menerima bantuan berupa benih cabai dan sarana produksi penunjang lainnya berupa pupuk, pestisida, mulsa dan alsintan untuk meningkatkan produksi cabai sehingga dapat meningkatkan pendapatan petani. Dengan adanya bantuan tersebut diharapkan bisa menjadi salah satu solusi untuk mengatasi permasalahan yang dialami oleh petani. Dari latar belakang yang telah diuraikan diatas penulis tertarik untuk melakukan penelitian untuk mengetahui Dampak Program Bantuan Saprodi Terhadap Pendapatan Petani Cabai di Desa Kauneran Kecamatan Sonder Kabupaten Minahasa.

\section{Deskripsi Umum Pogram Bantuan Saprodi}

Setiap tahun pemerintah pusat lewat Kementrian Pertanian telah meluncurkan program bantuan dibidang hortikultura kepada petani. Pada awal tahun 2017 bantuan ini diberikan kepada petani lewat Dinas Pertanian Kabupaten Minahasa. Tujuan dari program bantuan ini adalah untuk mengsejahterakan petani. Adapun kriteria yang mendapatkan bantuan program adalah kelompok tani yang memiliki sertifikat, program yang jelas dan fiktif.

\section{Usaha Tani Cabai}

Cabai adalah komuditas hortikultura yang sangat penting yang tidak bisa dipisahkan dari kebutuhan sehari-hari di dalam konsumsi rumah tangga tanpa memperhatikan tingkat sosial. Cabai mempunyai prospek cerah sebagai komuditas yang bernilai ekonomis tinggi karena salah satu pemanfaatannya sebagai bahan baku industri, dibutuhkan setiap saat sebagai bumbu masak, berpeluang ekspor, membuka kesempatan kerja dan sebagai sumber vitamin C Santika (2002).

Menurut Nawangsih (2003), kegiatan budidaya tanaman cabai terdiri dari:

a. Pengolahan tanah.

Tanah untuk tanaman cabai harus digemburkan, sehingga memenuhi persyaratan tumbuh cabai, pengolahan tanah secara umum meliputi penggemburan tanah, pemberian pupuk dasar dan pencangkulan ulang.

b. Persiapan tanam.

Persiapan sebelum penanaman diantaranya pembuatan bedengan untuk pembenihan, penyeleksian benih, penyemaian benih serta perawatan benih.

c. Penentuan jarak tanam.

Jarak tanam yang umum digunakan petani adalah $50-60 \mathrm{~cm}$ untuk jarak antar lubang dan $60-70 \mathrm{~cm}$ untuk jarak antar barisan.

d. Penanaman bibit.

13 Bibit yang siap ditanam merupakan bibit yang sudah berumur $21-25$ hari setelah penyemaian benih dan waktu penanaman sebaiknya dilakukan pada sore hari.

e. Pemupukan tanaman.

Seminggu setelah dilakukan penanaman, dapat dilakukan pemupukan awal. Jenis takaran pupuk yang digunakan tergantung daerah setempat, karena masing-masing daerah memerlukan jenis dan takaran pupuk yang berbeda. Perbedaan ini disebabkan oleh tingkat kesuburan tanah, struktur dan jenis tanah, keadaan alam, serta ketinggian tempat.

f. Pemanenan

Tanaman yang dapat dipanen pertama kali pada usia $70-75$ hari tergantung dari varietas yang ditanam. Untuk selanjutnya tanaman dapat dipanen secara terus menerus dengan selang waktu pemanenan 3 - 4 hari sekali. Namun yang umumnya dilakukan petani adalah seminggu sekali.

Sunarjono (2010), mengatakan cabai dapat tumbuh baik di dataran tinggi maupun dataran rendah. Akan tetapi, tanaman cabai tidak tahan terhadap hujan, terutama pada waktu berbunga karena bungabunganya akan mudah gugur. 


\section{Pendapatan}

Soeharjo dan patong (2007), menyatakan bahwa pendapata adalah balas jasa dari bekerjanya faktor-faktor produksi yang digunakan dalam proses produksi. Bekerjanya faktor-faktor produksi tersebut karena adanya kemampuan petani dalam mengelolahnya. Dalam meningkatkan pendapatan petani maka petani harus berusaha meningkatkan hasil produksi.

Sedangkan Menurut Mubyarto (2004), pendapatan adalah hasil pengurangan antara hasil penjualan dengan semua biaya yang dikeluarkan mulai dari produksi sampai produk tersebut berada di tangan konsumen. Berbeda dengan Sukirno (2006), dia mengatakan pendapatan adalah jumlah penghasilan yang diterima oleh penduduk atas prestasi kerjanya selama satu periode tertentu, baik harian, mingguan, bulanan, maupun tahunan.

Menurut Seokartawi (2003), pendapatan adalah selisi antara penerimaan dengan semua biaya. Dengan rumus sebagai berikut :

$$
\mathrm{I}=\mathrm{TR}-\mathrm{TC}
$$

Dimana :

$\begin{array}{lll}\mathrm{I} & = & \text { Income (pendapatan) } \\ \mathrm{TR} & = & \text { Total revenue (total penerimaan) } \\ \mathrm{TC} & = & \text { Total Cost (total biaya }\end{array}$

\section{Penerimaan}

Menurut Hernanto (1993), penerimaan usahatani yaitu penerimaan sumber-sumber usaha tani meliputi nilai jual hasil, penumbuhan jumlah investasi, nilai produk yang dikonsumsi petani, dan keluarganya.

Soekartawi (1995), mengatakan bahwa penerimaan usaha tani adalah perkalian atara produksi yang diperoleh dengan harga jual.

Pernyataan ini dapat ditulis sebagai berikut :

Yaitu :

$$
\mathrm{TR}=\mathrm{Y} \text {. Py }
$$

TR $=$ Total Penerimaan

$\mathrm{Y} \quad=$ Produksi yang diperoleh dalam suatu usahatani

Py $=$ Harga $Y$

\section{Uji T Berpasangan}

Uji $\mathrm{t}$ dua sampel berpasangan dilakukan untuk menguji apakah terdapat perbedaan rata-rata yang signifikan antara dua sampel berpasangan. Dua sampel berpasangan merupakan sebuah sampel dengan subjek yang sama namun mendapatkan dua perlakuan yang berbeda. Pengukuran pertama dilakukan sebelum diberi perlakuan tertentu dan pengukuran kedua dilakukan sesudahnya Sugiono (2011).

\section{Hipotesis Penelitian}

Hipotesis penelitian merupakan dugaan awal atau kesimpulan sementara hubungan pengaruh antara variabel independen terhadap variabel dependen sebelum dilakukan penelitian dan harus dibuktikan dalam penelitian.

Hipotesis adalah jawaban sementara terhadap rumusan masalah penelitian, dimana rumusan masalah telah dinyatakan dalam bentuk pertanyaan Sugiono (2011).

Hipotesis yang diajukan dalam penelitian ini adalah :

Ho: $\mu 1<\mu 2$, Tidak ada perbedaan pendapatan sebelum dan sesudah mendapatkan bantuan.

Ha: $\mu 1>\mu 2$, Ada perbedaan pendapatan sebelum dan sesudah mendapatkan bantuan.

\section{Rumusan Masalah}

Berdasarkan latar belakang tersebut, maka perumusan masalah adalah bagaimana dampak yang ditimbulkan dari Program Bantuan Sarana Produksi Pertanian Terhadap Pendapatan Petani Cabai di Desa Kauneran Kecamatan Sonder.

\section{Tujuan Penelitian}

Tujuan dari penelitian ini adalah untuk melihat dampak yang ditimbulkan dari Program Bantuan Sarana Produksi Pertanian terhadap Pendapatan Petani Cabai di Desa Kauneran Kecamatan Sonder.

\section{Manfaat Penelitian}

Manfaat dari penelitian ini adalah sebagai berikut:

1. Bagi peneliti dapat melatih cara berpikir serta menganalisis data dan penelitian ini merupakan salah satu syarat untuk memperoleh gelar sarjana di fakultas Pertanian Universitas Sam Ratulangi Manado.

2. Bagi pihak pemerintah setempat dan Dinas Pertanian Kabupatan Minahasa agar menyusun program dan kebijakan yang mampu meningkatkan tingkat keuntungan hasil dari petani sehingga terjadi peningkatan keluarga petani.

3. Bagi peneliti lain dapat menjadi referensi kajian dalam bidang penelitian seru. 


\section{METODE PENELITIAN}

\section{Waktu dan Tempat Penelitian}

Penelitian ini dilaksanakan selama 3 bulan yaitu mulai dari bulan Maret 2018 sampai Mei 2018 mulai dari persiapan sampai penyusunan laporan penelitian. Tempat penelitian ini dilaksanakan di Desa Kauneran, Kecamatan Sonder, Kabupaten Minahasa.

\section{Metode Pengumpulan Data}

Penelitian ini menggunakan data primer dan data sekunder. Data primer diperoleh dari pengamatan dan wawancara langsung dengan responden berdasarkan daftar pertanyaan (kuesioner) dengan data yang diperlukan adalah data sebelum dan sesudah mendapatkan bantuan, sedangkan data sekunder dikumpulkan dan diperoleh melalui instansi yang terkait dengan penelitian ini antara lain Kantor Desa Kauneran Kecamatan Sonder Kabupaten Minahasa.

\section{Metode Pengambilan Sampel}

Pengambilan sampel dalam penelitian ini dilakukan dengan wawancara terhadap seluruh petani cabai dengan jumlah 20 responden yang menerima bantuan sebelum dan sesudah di kelompok tani Kalelon.

\section{Konsep Pengukuran Variabel}

Adapun variabel yang akan diukur dalam penelitian ini baik sebelum dan sesudah menerima bantuan adalah pendapatan petani cabai.

Pendapatan diperoleh dari selisih antara penerimaan dan biaya

Variabel-variabel pendapatan adalah :

1. Penerimaan yaitu Perkalian antara jumlah produksi dan harga jual selama satu kali penanaman,

2. Biaya yaitu biaya yang dikeluarkan petani selama proses produksi cabai selama satu kali penanaman yang terdiri dari :

a. Biaya tetap :

- Pajak (Rp)

- Penyusunan alat bangunan (Rp)

b. Biaya variabel :

- Benih (Rp)

- Pupuk (Rp)

- Pestisida (Rp)

- Tenaga kerja $(\mathrm{Rp})$

- Sewa pengankutan (Rp)

3. Status lahan yang digunakan (Milik sendiri, pinjam/lainnya)

4. Produksi yaitu jumlah produksi usaha tani cabai (kg) dalam ukuran waktu satu kali penanaman
5. Harga yaitu harga yang berlaku ditingkat petani ( Rp/kg)

Selain itu diperlukan variabel lain yaitu :

6. Karakteristik responden yaitu :

a. Umur petani

b. Tingkat Pendidikan (SD,SMP,SMA,PT)

\section{Metode Analisis Data}

Dalam penelitian ini metode analisis data yang di gunakan adalah analisis kuantitatif yaitu model analisis data berdasarkan atas hasil statistik, dan menggunakan Uji beda rata-rata menggunakan rumus Uji-T (Sampel berpasangan) karena yang akan di hitung adalah pendapatan petani sebelum dan sesudah menerima bantuan program, dengan menggunakan aplikasi minitab.

\section{HASIL DAN PEMBAHASAN}

\section{Deskripsi Daerah Penelitian}

\section{Keadaan Geografis Lokasi Penelitian}

Desa Kauneran merupakan salah satu desa di kecamatan Sonder dengan luas wilayah 254 ha. Desa Kauneran terdiri dari IV jaga. Batas Desa Kauneran:
a. Sebelah Utara
: Desa Kauneran Satu
b. Sebelah Timur
: Desa Kiawa
c. Sebelah Selatan
: Desa Sendangan
d. Sebelah Barat
: Desa Tincep

\section{Jumlah Penduduk}

Jumlah Penduduk yang berada di desa Kauneran Kecamatan Sonder dapat dilihat pada Tabel 1.

\begin{tabular}{clr}
\multicolumn{2}{c}{ Tabel 1. Jumlah Penduduk Menurut Jenis Kelamin } & \\
\hline No & Jenis Kelamin & Jumlah Penduduk (Orang) \\
\hline 1 & Laki-laki & 561 \\
2 & Perempuan & 511 \\
\hline & Jumlah & 1.072 \\
\hline \multicolumn{2}{l}{ Sumber : } & Diperoleh dari Kantor Desa Kauneran 2018
\end{tabular}

\section{Deskripsi Kelompok Tani}

\section{Sejarah Singkat Terbentuknya Kelompok Tani Kalelon}

Kelompok Tani Kalelon merupakan salah satu dari beberapa kelompok tani yang ada di Kecamatan Sonder yang berdiri pada tanggal 28 Februari 1997. Terbentuknya Kelompok Tani Kalelon di motivasi karena sebagian besar petani pada waktu itu masih kekurangan ilmu bercocok tanam, sehingga mereka membentuk kelompok tani untuk merangkul para petani agar bisa bercocok tanam dan saling berbagi ilmu tentang pertanian dan 
cara menggunakan teknologi pertanian agar bias meningkatkan hasil pertanian dan mampu mensejahterakan anggota kelompok tani. Kalelon merupakan bahasa daerah Minahasa lebih khusus bahasa Tontemboan dalam bahasa Manado Kalelon memiliki arti 'dapa-dapa inga' atau 'sayang-sayang' kemudian dibuatlah berita acara pembentukan kelompok tani kemudian pada bulan 28 Februari 2009 kelompok tani dikukuhkan oleh Pemerintah Kabupatan Minahasa, sampai saat ini yang di ketua oleh bapak Ferdie Turanban.

\section{Struktur Organisasi}

Setiap organisasi atau kelompok pasti memiliki struktur kelompok agar terdapat pembagian tugas yang jelas dalam setiap kegiatan yang dijalankan sehingga dapat direalisaikan dengan baik.

\begin{tabular}{ll}
\multicolumn{3}{c}{ Struktur } & organisasi kelompok tani \\
Ketua & : Bpk. Ferdie Turangan \\
Sekertaris & : Bpk. Samy Senduk \\
Bendahara & : Bpk. Decky Sangkilen \\
Anggota & : Bpk. Max Ruus \\
& Bpk. Hence Mamile \\
& Bpk. Koyo Ruus \\
& Bpk. Rudy Lolowang \\
& Bpk. Sony Mandagi \\
& Bpk. Jan Wokas \\
& Bpk. Joudy Menajang \\
& Bpk. Alfrets Menajang \\
& Bpk. Ary Oroh \\
& Bpk. Ferdi Pesik \\
& Bpk. Hery Emor \\
Bpk. Hery Mawei \\
Bpk. Jendry Runtu \\
Bpk. Joppi Rumengan \\
Bpk. Refli Hihola \\
Bpk. Roy Ruus \\
Bpk. Seifanto Senduk
\end{tabular}

\section{Jenis Usaha Tani yang ditekuni}

Adapun jenis usaha tani yang ditekuni oleh kelompok tani Kalelon adalah:

- Cabai

- Jagung

- Bawang Merah

\section{Bantuan Sarana Produksi dari Pemerintah Untuk Kelompok Tani Kalelon}

Adapun jenis bantuan yang diterima oleh kelompok tani Kalelon dapat dilihat pada Tabel 2 .
Tabel 2. Bantuan Saprodi dari Pemerintah Untuk Kelompok

\begin{tabular}{lc}
\begin{tabular}{l} 
Tabel 2. \\
\multicolumn{1}{c}{ Bantuan Kalelon } \\
Janis
\end{tabular} & Jumlah (unit) \\
\hline \multicolumn{1}{c}{ Benih (saset) } & 40 \\
Pupuk Mutiara (sak) & 20 \\
Pupuk Cair (liter) & 80 \\
Fungisida (liter) & 20 \\
Mulsa (rol) & 28 \\
Deltomik (sak) & 40 \\
Hand Tractor & 1 \\
\hline
\end{tabular}

Masing-masing responden mendapatkan jenis-jenis bantuan sesuai kebutuhan yang akan digunakan. Perbedaan sebelum dan sesudah menerima bantuan dalam meningkatkan produksi cabai yaitu :

Sebelum menerima bantuan animo para petani kurang, benih yang digunakan benih lokal, peralatan yang digunakan masih bersifat sederhana, kurangnya pengetahuan akan pengendalian hama penyakit dan kualitas buah yang dihasilkan sedikit yang mengakibatkan hasil produksi kurang.

Sesudah menerima bantuan animo para petani meningkat, benih yang digunakan adalah benih varietas unggul, buah yang dihasilkan yang dulunya sedikit, setelah menggunakan benih dari pemerintah buah yang dihasilkan lebat, peralatan yang digunakan sudah tersedia yang memudahkan para petani untuk bekerja yang dulunya hanya mencangul tanah dengan menghabiskan waktu yang lama kemudian setelah menerima bantuan waktu yang dibutuhkan hanya singkat karna telah menggunakan traktor, pestisida sudah tersedia, sudah memakai teknologi yang berdampak pada hasil yang memuaskan.

\section{Karakteristik Responden}

\section{Usia Responden}

Usia responden penerima bantuan saprodi dapat dilihat pada Tabel 3.

\begin{tabular}{lcr} 
Tabel 3. Jumlah Responden menurut Tingkat Usia & \\
\hline Usia & Jumlah & Persentase (\%) \\
\hline $30-40$ & 3 & 15 \\
$41-50$ & 6 & 30 \\
$51-60$ & 8 & 40 \\
$61-70$ & 3 & 15 \\
\hline Jumlah & 20 & 100 \\
\hline Sumber : Data primer diolah, 2018 &
\end{tabular}

Tabel 3 menunjukkan bahwa penerima bantuan saprodi memiliki umur 30-40 tahun berjumlah 3 orang dengan persentase $15 \%$, umur 41 50 tahun berjumlah 6 orang dengan persentase $30 \%$, 51-60 tahun berjumlah 8 orang dengan persentase $40 \%$, 61-70 tahun berjumlah 3 orang dengan persentase $15 \%$. kebanyakan responden yang menerima bantuan saprodi ada disekitar umur 51-60 tahun. 


\section{Pendidikan Responden}

Pendidikan responden penerima bantuan saprodi dapat dilihat pada Tabel 4.

Tabel 4. Jumlah Responden menurut Tingkat

Pendidikan

\begin{tabular}{lcr}
\hline Pendidikan & Jumlah & Persentase (\%) \\
\hline SD & 8 & 40 \\
SMP & 6 & 30 \\
SMA & 4 & 20 \\
Perguruan Tinggi & 2 & 10 \\
\hline Jumlah & 20 & 100 \\
\hline
\end{tabular}

Sumber : Data primer diolah, 2018

Tabel 4 menunjukkan bahwa penerima bantuan saprodi dengan tingkat pendidikan SD berjumlah 8 orang dengan persentase $40 \%$, tingkat pendidikan SMP berjumlah 6 orang dengan persentase $30 \%$, tingkat pendidikanSMA berjumlah 4 orang dengan persentase $20 \%$, dan tingkat pendidikan di perguruan Tinggi berjumlah 2 orang denga persentase $10 \%$. Ini menunjukan bahwa tingkat pendidkan responden yang paling banyak ada ditingkat SD dengan jumlah responden 8 responden.

\section{Status Lahan}

Status lahan yang digunakan responden sebelum dan sesudah menerima bantuan saprodi dapat dilihat pada Tabel 5.

\begin{tabular}{lccr}
\multicolumn{4}{c}{ Tabel 5. Status Lahan yang Digunakan Responden } \\
\hline Status Lahan & Jumlah Responden & Luas (ha) & Persentase (\%) \\
\hline Milik Sendiri & 11 & 4,2 & 65 \\
Pinjam & 9 & 3,6 & 45 \\
Sewa & 0 & 0 & 0 \\
\hline Jumlah & 20 & 7,8 & 100 \\
\hline Sumber : Data primer diolah, 2018 & &
\end{tabular}

Tabel 5 menunjukkan bahwa Status lahan yang digunakan berdasarkan milik sendiri berjumlah 11 orang dengan persentase $65 \%$, pada status lahan pinjam berjumlah 9 orang dengan persentase $45 \%$. Ini menunjukan bahwa status lahan yang digunakan sebelum dan sesudah meneriman bantuan saprodi paling banyak menggunakan lahan milik sendiri.

\section{Luas Lahan}

Luas lahan responden sebelum dan sesudah menerima bantuan saprodi dapat dilihat pada Tabel 6.

\begin{tabular}{ccccc} 
Tabel 6. Rata-rata luas lahan yang digunakan responden \\
\hline \multirow{3}{*}{ Uraian } & \multicolumn{4}{c}{ Luas Lahan (ha) } \\
\cline { 2 - 5 } & \multicolumn{3}{c}{ Sebelum } & \multicolumn{3}{c}{ Sesudah } \\
\cline { 2 - 5 } & Per Petani & Per Hektar & Per Petani & Per Hektar \\
\hline Jumlah & 0,39 & 1 & 0,39 & 1 \\
\hline Sumber : Data primer diolah, 2018 & 1 & 0,39 & 1 \\
\end{tabular}

Tabel 6 menunjukkan bahwa rata-rata luas lahan yang digunakan responden sebelum mendapatkan bantuan sebasar 0,39 ha dengan ratarata per hektar 1 ha.

\section{Produksi}

Produksi adalah hasil jumlah produksi yang diperoleh petani dapat dilihat pada Tabel 7 .

Tabel 7. Rata-rata Produksi Petani Sebelum dan Sesudah Menerima Bantuan Saprodi

\begin{tabular}{ccccc}
\multicolumn{3}{c}{ Bantuan Saprodi } \\
\cline { 2 - 5 } Uraian & \multicolumn{2}{c}{ Sebelum } & \multicolumn{2}{c}{ Sesudah } \\
\cline { 2 - 5 } & Per Petani & Per Hektar & Per Petani & Per Hektar \\
\hline Jumlah & 1490 & $3.820,51$ & 4000 & $10.256,41$ \\
\hline Sumber : Data primer diolah, 2018 & 1490 & $3.820,51$ & 4000 & $10.256,41$ \\
\hline
\end{tabular}

Tabel 7 menunjukkan bahwa rata-rata produksi cabai petani sebelum menerima bantuan didapat dengan jumlah produksi $1490 \mathrm{~kg}$ dengan rata-rata per hektar 3.820,51 dan sesudah didapat jumlah produksi $4000 \mathrm{~kg}$ dengan rata-rata per hektar 10.256,41. Hal ini menunjukan bahwa produksi yang didapat oleh petani sesudah menerima bantuan mengalami peningkatan.

\section{Penerimaan}

Penerimaan sebelum dan sesudah menerima bantuan Saprodi berdasarkan penerimaan hasil produksi petani yaitu perkalian antara jumlah produksi dan harga jual dapat dilihat pada Tabel 8.

Tabel 8. Rata-rata Penerimaan petani sebelum dan sesudah menerima Saprodi

\begin{tabular}{lrrrr}
\hline \multirow{2}{*}{ Uraian } & \multicolumn{3}{c}{ Penerimaan (Rp) } \\
\cline { 2 - 5 } & \multicolumn{2}{c}{ Sebelum } & \multicolumn{2}{c}{ Sesudah } \\
\cline { 2 - 5 } & Per Petani & Per Hektar & Per Petani & \multicolumn{1}{c}{ Per Hektar } \\
\hline Produksi (kg) & 1.490 & $3.820,51$ & 4.000 & $10.256,41$ \\
Harga Jual (Rp) & 25.000 & 25.000 & 25.000 & 25.000 \\
Penerimaan (Rp) & 37.250 .000 & $95.512 .820,51$ & 100.000 .000 & $256.410 .256,41$ \\
\hline Sumber : Data primer diolah, 2018 & & &
\end{tabular}

Tabel 8 menunjukkan bahwa rata-rata produksi per petani sebelum menerima bantuan didapat $1.490 \mathrm{~kg}$ dengan rata-rata per hektar $3.820,51 \mathrm{~kg}$ dengan harga jual Rp. $2500 / \mathrm{kg}$ sehingga mendapatkan rata-rata penerimaan per petani sebesar Rp. 37.250.000 dengan rata-rata per hektar Rp. 95.512.820,51 dan rata-rata produksi per petani sesudah menerima bantuan didapat $4000 \mathrm{~kg}$ dengan rata-rata per hektar 10.256,41 dengan harga jual $\mathrm{Rp}$. $25.000 / \mathrm{kg}$ sehingga mendapatkan rata-rata penerimaan per petani sebesar Rp. 100.000.000 dengan rata-rata per hektar Rp. 256.410.256,41. Hal ini menunjukan bahwa sesudah menerima bantuan saprodi penerimaan petani mengalami peningkatan. Hal ini di ikuti dengan bertambahnya jumlah produksi. 


\section{Pengeluaran}

Pengeluaran sebelum dan sesudah menerima bantuan Saprodi berdasarkan penjumlahan dari (pajak, penyusutan alat, tenaga kerja, pupuk, pestisida, benih, transportasi, dan lain-lain) dapat dilihat pada Tabel 9.

Tabel 9. Biaya Produksi Cabai Sebelum dan Sesudah Bantuan (Biaya Tidak diperhitungkan)

\begin{tabular}{|c|c|c|c|c|c|}
\hline \multirow{3}{*}{ No } & \multirow{3}{*}{$\begin{array}{c}\text { Jenis } \\
\text { Pengeluaran }\end{array}$} & \multicolumn{4}{|c|}{ Pengeluaran (Rp) } \\
\hline & & \multicolumn{2}{|c|}{ Sebelum } & \multicolumn{2}{|c|}{ Sesudah } \\
\hline & & Per Petani & Per Hektar & Per Petani & Per Hektar \\
\hline 1 & Pajak & 0 & 0 & 0 & 0 \\
\hline 2 & Sewa Alat & 100.000 & $256,410,25$ & 0 & 0 \\
\hline \multirow[t]{5}{*}{3} & Pupuk : & & & & \\
\hline & Urea & 99.000 & $235.846,15$ & 0 & 0 \\
\hline & Phonska & 114.000 & $292.307,69$ & 0 & 0 \\
\hline & Mutiara & 0 & 0 & 0 & 0 \\
\hline & Cair & 0 & 0 & 0 & 0 \\
\hline 4 & Deltomik & 0 & 0 & 0 & 0 \\
\hline 5 & Pestisida & 40.000 & $102.564,10$ & & \\
\hline 6 & Benih & 0 & 0 & 0 & 0 \\
\hline 7 & Mulsa & 500.000 & $1.282 .051,28$ & 0 & 0 \\
\hline 8 & Tenaga Kerja & 834.000 & $2.138 .461,53$ & 1.536 .000 & $3.938 .461,53$ \\
\hline 9 & Transportasi & 400.000 & $1.025 .641,02$ & 448.000 & $1.148 .717,94$ \\
\hline \multirow[t]{2}{*}{10} & Lain-lain & 1.150 .000 & $2.948 .717,94$ & 1.150 .000 & $2.948 .717,94$ \\
\hline & Total & 3.237 .000 & $8.281 .997,29$ & 3.134 .000 & $7.035 .897,41$ \\
\hline
\end{tabular}

Tabel 9 menunjukkan bahwa rata-rata pengeluaran per petani sebelum menerima bantuan sebesar Rp. 3.237.000 dengan rata-rata pengeluaran per hektar Rp. 8.281.997,29 dan ratarata pengeluaran per petani sesudah menerima bantuan sebesar Rp. 3.134.000 dengan rata-rata pengeluaran per hektar Rp. 7.035.897,41.

Tabel 10. Biaya Produksi Cabai Sebelum dan Sesudah Bantuan (Bantuan diperhitungkan)

\begin{tabular}{clrrrr}
\hline \multirow{2}{*}{ No } & \multirow{2}{*}{ Jenis } & \multicolumn{4}{c}{ Pengeluaran (Rp) } \\
\cline { 3 - 6 } & Pengeluaran & \multicolumn{2}{c}{ Sebelum } & \multicolumn{2}{c}{ Sesudah } \\
\cline { 3 - 6 } & Per Petani & Per Hektar & Per Petani & Per Hektar \\
\hline 1 & 0 & 0 & 0 & 0 \\
2 & Sewa Alat & 100.000 & $256,410,25$ & 350.000 & 897.435 .89 \\
3 & Pupuk: & & & & \\
& Urea & 99.000 & $235.846,15$ & & \\
& Phonska & 114.000 & $292.307,69$ & & \\
& Mutiara & 0 & 0 & 42.500 & $108.974,35$ \\
& Cair & 0 & 0 & 320.000 & $820.512,82$ \\
4 & Deltomik & 0 & 0 & 150.000 & $384.615,38$ \\
5 & Pestisida & 40.000 & $102.564,10$ & 60.000 & $153,846,15$ \\
6 & Benih & 0 & & 80.000 & $205.128,20$ \\
7 & Mulsa & 500.000 & $1.282 .051,28$ & 500.000 & $1.282 .051,28$ \\
8 & Tenaga Kerja & 834.000 & $2.138 .461,53$ & 1.536 .000 & $3.938 .461,53$ \\
9 & Transportasi & 400.000 & $1.025 .641,02$ & 448.000 & $1.148 .717,94$ \\
10 & Lain-lain & 1.150 .000 & $2.948 .717,94$ & 1.150 .000 & $2.948 .717,94$ \\
\hline & Total & 3.237 .000 & $8.281 .997,29$ & 4.636 .500 & $11.888 .456,54$ \\
\hline
\end{tabular}

Sumber : Data primer diolah, 2018

Tabel 10 menunjukkan bahwa rata-rata pengeluaran per petani sebelum menerima bantuan sebesar Rp. 3.237.000 dengan rata-rata pengeluaran per hektar Rp. 8.281.997,29 dan ratarata pengeluaran per petani sesudah menerima bantuan sebesar Rp. 4.636.500 dengan rata-rata pengeluaran per hektar Rp. 11.888.456,54.

\section{Pendapatan}

Pendapatan sebelum dan sesudah menerima bantuan Saprodi berdasarkan pendapatan hasil produksi petani yaitu pengurangan antara jumlah penerimaan dan jumlah pengeluaran dapat dilihat pada Tabel 11 .

Tabel 11. Pendapatan Usahatani Cabai Sebelum dan Sesudah Bantuan (Bantuan Tidak diperhitungkan)

\begin{tabular}{lcrrr}
\hline \multirow{2}{*}{ Uraian } & \multicolumn{3}{c}{ Pendapatan (Rp) } \\
\cline { 2 - 3 } & \multicolumn{2}{c}{ Sebelum } & \multicolumn{2}{c}{ Sesudah } \\
\cline { 2 - 3 } & Per Petani & \multicolumn{1}{c}{ Per Hektar } & Per Petani & \multicolumn{1}{c}{ Per Hektar } \\
\hline Penerimaan (Rp) & 37.250 .000 & $95.512 .820,51$ & 100.000 .000 & $256.410 .256,41$ \\
Pengeluaran (Rp) & 3.237 .000 & $8.281 .997,29$ & 3.134 .000 & $7.035 .897,41$ \\
Pendapatan (Rp) & 34.013 .000 & $87.230 .823,22$ & 96.866 .000 & $249.374 .359,01$ \\
\hline Sumber : Data primer diolah, 2018 & & &
\end{tabular}

Tabel 11 menunjukkan bahwa rata-rata penerimaan per petani sebelum menerima bantuan sebesar Rp. 37.250.000 dengan rata-rata per hektar Rp. 95.512.820,51 dan rata-rata pengeluaran per petani sebesar Rp. 3.237.000 dengan rata-rata per hektar Rp. 8.281.997,29 sehingga diperoleh rata-rata pendapatan sebesar Rp. 34.013.000 dengan rata-rata per hektar Rp. 87.230.823,22 dan sesudah menerima bantuan rata-rata penerimaan per petani sebesar 100.000.000 dengan rata-rata per hektar $\mathrm{Rp}$. 256.410.256,41 dan rata-rata pengeluaran per petani sebesar 3.134.000 dengan rata-rata per hektar Rp. 7.035.897,41 sehingga diperoleh ratarata pendapatan sebesar Rp. 96.866.000 dengan rata-rata per hektar Rp. 249.374.359,01.

Tabel 12. Pendapatan Usahatani Cabai Sebelum dan Sesudah Bantuan (Bantuan diperhitungkan)

\begin{tabular}{lrrrr}
\hline \multirow{2}{*}{ Uraian } & \multicolumn{2}{c}{ Pendapatan (Rp) } \\
\cline { 2 - 5 } & \multicolumn{2}{c}{ Sebelum } & \multicolumn{2}{c}{ Sesudah } \\
\cline { 2 - 5 } \cline { 2 - 4 } Per Petani & \multicolumn{1}{c}{ Per Hektar } & Per Petani & \multicolumn{1}{c}{ Per Hektar } \\
\hline Penerimaan (Rp) & 37.250 .000 & $95.512 .820,51$ & 100.000 .000 & $256.410 .256,41$ \\
Pengeluaran (Rp) & 3.237 .000 & $8.281 .997,29$ & 4.636 .500 & $11.888 .456,54$ \\
Pendapatan (Rp) & 34.013 .000 & $87.230 .823,22$ & 95.363500 & $244.521 .800,87$ \\
\hline Sumber : Data primer diolah, 2018
\end{tabular}

Tabel 12 menunjukkan bahwa rata-rata penerimaan per petani sebelum menerima bantuan sebesar Rp. 37.250.000 dengan rata-rata per hektar Rp. 95.512.820,51 dan rata-rata pengeluaran per petani sebesar Rp. 3.237.000 dengan rata-rata per hektar Rp. 8.281.997,29 sehingga diperoleh rata-rata pendapatan sebesar Rp. 34.013.000 dengan rata-rata per hektar Rp. 87.230.823,22 dan sesudah menerima bantuan rata-rata penerimaan per petani sebesar 100.000.000 dengan rata-rata per hektar Rp. 256.410.256,41 dan rata-rata pengeluaran per petani sebesar 4.636.500 dengan rata-rata per hektar Rp. sehingga diperoleh rata-rata pendapatan sebesar $\mathrm{Rp}$. 95.363.500 dengan rata-rata per hektar Rp. $244.521 .800,87$. 


\section{Analisis uji beda rata-rata}

Pengujian beda rata-rata Pendapatan sebelum dan sesudah menerima bantuan Saprodi

Pendapatan petani sesudah menerima bantuan lebih tinggi dari pada sebelum menerima bantuan ( $\mathrm{P}$ $<0,01)$ atau perbedaannya sangat nyata.

\section{KESIMPULAN DAN SARAN}

\section{Kesimpulan}

Program bantuan sarana produksi pertanian usahatani cabai pada petani yang tergolong dalam kelompok tani kalelon di desa kauneran Kecamatan Sonder Kabupaten Minahasa berdampak meningkatkan produksi dan pendapatan petani.

\section{Saran}

1. Buat pemerintah agar supaya bantuan yang telah diberikan agar supaya bisa di salurkan secara berkelanjutan.

2. Buat petani agar supaya tetap menggunakan serta memanfaatkan bantuan yang telah diberikan dengan sebaik-baiknya dan tetap mempertahankan peningkatan pendapatan yang didapat.

\section{DAFTAR PUSTAKA}

Hernanto, 1993.Ilmu usahatani. Penebar Swadaya. Jakarta.

Mubyarto, 2004. Pengantar Ekonomi Pertanian. LP3ES Jakarta.

Nawangsih, 2003. Cabai Hot Beauty.Bogor: Penebar Swadaya.

Santika, Adhi. 2002. Agribisnis Cabai Hibrida. Penebar Swadaya. Jakarta.

Soekartawi, 1995. Pengantar Ekonomi Pertanian. LP3ES. Jakarta.

Sugiono, 2011. Metode Penelitian Kuantitatif Kualitatif dan R \& D. Cv. Alfabeta. Bandung. 